\title{
PERFORMANS BURUNG PUYUH (Coturnix - coturnix japonica) YANG DIBERIKAN TEPUNG KEONG SAWAH (Pila ampullacea) SEBAGAI PENGGANTI TEPUNG IKAN DALAM RANSUM
}

\author{
Fransela The, Ch. L. K. Sarajar, M. E. R. Montong*, M. Najoan \\ Fakultas Peternakan Universitas Sam Ratulangi Manado, 95115
}

\begin{abstract}
ABSTRAK
Penelitian ini bertujuan untuk mengetahui sejauh mana penggunaan Tepung Keong Sawah (Pila ampullacea) sebagai pengganti tepung ikan dalam ransum terhadap performans burung puyuh (Coturnix - coturnix japonica). Penelitian ini menggunakan 60 ekor burung puyuh betina berumur 5 minggu dan untuk pengumpulan data dilakukan 8 minggu. Rancangan yang digunakan adalah rancangan acak lengkap (RAL) yang terdiri dari 4 perlakuan dan 5 ulangan. Perlakuan tersebut adalah tepung keong sawah dengan beberapa tingkat pemberian dalam ransum, yaitu: $\mathrm{R} 0=0 \%$ tepung keong sawah $+15 \%$ tepung ikan, $\mathrm{R} 1=5 \%$ tepung keong sawah $+10 \%$ tepung ikan ,R2 $=10 \%$ tepung keong sawah + $5 \%$ tepung ikan dan R3 $=15 \%$ tepung keong sawah $+0 \%$ tepung ikan. Variabel yang diukur guna untuk melihat respons burung puyuh terhadap tepung keong sawah adalah konsumsi ransum, produksi telur dan konversi ransum. Hasil analisis keragaman menunjukkan bahwa perlakuan tidak berbeda nyata $(\mathrm{P}>0,05)$ terhadap konsumsi ransum, produksi telur dan konversi ransum. Berdasarkan hasil penelitian ini menunjukkan tepung keong sawah sampai level $15 \%$ dapat digunakan sebagai pengganti tepung ikan dalam ransum burung puyuh.
\end{abstract}

Kata kunci : burung puyuh, keong sawah, performans, dan tepung ikan

\section{ABSTRACT \\ PERFORMANS OF QUAIL (Coturnix - coturnix japonica) PROVIDED CONCH PADDY (Pila ampullacea) FLOUR AS A}

*Korespondensi (corresponding Author)

Email : martinamontong@gmail.com
SUBSTITUTE FOR FISH FLOUR IN THE RATION. This research aims to determine the extent to which the use of conch paddy (Pila ampullacea) flour as a substitute for fish flour in the ration on the performances of Quail (Coturnix- Coturnix japonica). This research used 60 quail 5-week-old female and for data collection was performed 8 weeks. The design used was a completely randomized design (CRD), which consists of 4 treatments and 5 replications. Such treatment is the conch paddy flour with some level of giving in the ration, which is : $\mathrm{R} 0=0 \%$ conch paddy flour $+15 \%$ fish flour, $\mathrm{R} 1=5 \%$ conch paddy flour $+10 \%$ fish flour, R2 $=10 \%$ conch paddy flour $+5 \%$ fish flour, and R3 = $15 \%$ conch paddy flour + $0 \%$ fish flour. Variables measured in order to see the response of quail to the conch paddy flour is feed consumption, egg production and feed conversion. Results of analysis of variance showed that the treatment was not significantly different on feed consumption, egg production and feed conversion. Based on the results of this research indicate conch paddy flour up to the level of $15 \%$ can be used as a substitute for fish flour in the ration of quail.

Keywords : quail, conch paddy, performances, and fish flour

\section{PENDAHULUAN}

Burung puyuh (coturnix-coturnix japonica) merupakan unggas yang sudah banyak diternakkan karena produksi telurnya tinggi. Produksi telur burung 
puyuh dalam satu tahun berkisar antara 200-300 butir (Amo et al., 2013).

Pakan yang dberikan pada burung puyuh harus mengandung nutrisi yang sesuai kebutuhan burung puyuh fase layer. Salah satu hal yang terpenting dalam pemeliharaan burung puyuh adalah pakan lengkap (Widyatmoko et al., 2013). Pada umumnya, peternak burung puyuh memberikan pakan dalam bentuk jadi dari perusahaan pakan atau membuat ransum sendiri dengan pengetahuan yang kurang tanpa pengetahuan jenis bahan pakan burung puyuh.

Tepung ikan merupakan salah satu pakan sumber protein yang kandungan proteinnya $55 \%-62 \%$ karena kandungan protein yang cukup tinggi sehingga peternak banyak menggunakan tepung ikan, sebab itu indonesia masih harus mengimport tepung ikan dari berbagai negara. Tepung ikan adalah bahan baku pakan yang mahal harganya karena belum dapat dipenuhi produksi dalam negeri (Sugiantoro dan Nurul, 2013). Oleh karena itu sebagai salah satu alternatif diperlukan pengganti dari tepung ikan yang memiliki kandungan protein yang hampir sama.

Salah satu bahan yang dapat dijadikan bahan pakan sumber protein adalah keong sawah. Keong sawah merupakan salah satu masalah hama utama dalam produksi padi. Untuk mengendalikan hama keong sawah, banyak petani yang memilih menggunakan moluskisida sintesis. Namun cara ini tidak efektif, selain karena harganya mahal, dalam 2-3 hari akan muncul generasi baru keong sawah yang siap menyerang tanaman. Oleh karena itu salah satu cara untuk mengendalikan keong sawah sebagai musuh besar petani yaitu dengan cara mengambil dan memanfaatkan keong sawah sebagai salah satu bahan pakan ternak yang memiliki kandungan protein $15 \%$ setelah dijadikan tepung keong sawah.

Dari pemikiran ini maka telah dilakukan penelitian yang berjudul performans burung puyuh (Coturnixcoturnix japonica) yang diberikan tepung keong sawah sebagai pengganti tepung ikan dalam ransum.

\section{MATERI DAN METODE PENELITIAN}

Penelitian ini telah di laksanakan di kandang Fakultas Peternakan Universitas Sam Ratulangi Manado, Sejak tanggal 8 April 2016 sampai 10 Juni 2016 yang terdiri dari 8 minggu pengambilan data. Penelitian ini menggunakan 60 ekor burung puyuh betina yang berumur 5 minggu. 
Tabel 1. Komposisi Zat-zat Bahan Makanan Penyusun Ransum

\begin{tabular}{lcccccc}
\hline \multicolumn{1}{c}{ Bahan Makanan } & Protein & SK & Lemak & Ca & P & EM \\
\hline Jagung ${ }^{1)}$ & 9,42 & 2,15 & 3,90 & 0,22 & 0,60 & 2982,00 \\
Dedak halus $^{1)}$ & 13,44 & 6,35 & 6,07 & 0,19 & 0,73 & 2696,00 \\
Tepung kedele $^{2)}$ & 37,50 & 2,00 & 12,52 & 0,24 & 0,28 & 2540,00 \\
Tepung Ikan $^{1)}$ & 55,59 & 0,02 & 12,10 & 5,10 & 2,08 & 3880,00 \\
Tepung Keong sawah $^{4)}$ & 15,00 & 6,09 & 2,40 & 5,87 & 0,96 & $900,67^{5)}$ \\
Bungkil kelapa $^{1)}$ & 24,74 & 15,02 & 9,36 & 0,11 & 0,47 & 3200,00 \\
$\mathrm{CaCO}_{3}{ }^{3)}$ & & & & 40,00 & & \\
\hline
\end{tabular}

${ }^{1}$ Menurut Dengah et al. (2016)

${ }^{2}$ Menurut NRC (1994)

${ }^{3}$ Menurut Scott et al. (1982)

${ }^{4}$ Hasil Analisis Laboratorium Ilmu dan Teknologi Pakan Fakultas Peternakan IPB.

${ }^{5}$ Menurut Paputungan (1984)

Tabel 2. Komposisi Ransum Penelitian

\begin{tabular}{lcccc}
\hline \multirow{2}{*}{ Bahan Makanan } & \multicolumn{4}{c}{ Perlakuan $(\%)$} \\
\cline { 2 - 5 } & $\mathrm{R} 0$ & $\mathrm{R} 1$ & $\mathrm{R} 2$ & $\mathrm{R} 3$ \\
\hline Jagung & 52,00 & 52,00 & 52,00 & 52,00 \\
Dedak halus & 10,00 & 10,00 & 10,00 & 10,00 \\
Tepung kedele & 13,00 & 13,00 & 13,00 & 13,00 \\
Tepung ikan & 15,00 & 10,00 & 5,00 & 0,00 \\
Tepung Keong sawah & 0,00 & 5,00 & 10,00 & 15,00 \\
Bungkil kelapa & 8,00 & 8,00 & 8,00 & 8,00 \\
CaCO 3 & 2.00 & 2,00 & 2,00 & 2,00 \\
\hline Total & $\mathbf{1 0 0}$ & $\mathbf{1 0 0}$ & $\mathbf{1 0 0}$ & $\mathbf{1 0 0}$ \\
\hline
\end{tabular}

Tabel 3. Kandungan Zat-zat Makanan Ransum Percobaan

\begin{tabular}{lcccc}
\hline \multicolumn{1}{c}{ Kandungan Zat-zat Makanan } & R0 & R1 & R2 & R3 \\
\hline Protein (\%) & 20,78 & 19,41 & 17,38 & 15,35 \\
SK (Serat Kasar) (\%) & 3,22 & 3,52 & 3,82 & 4,13 \\
Lemak (\%) & 6,83 & 6,34 & 5,86 & 5,37 \\
Ca (Kalsium) (\%) & 1,74 & 1,78 & 1,82 & 1,85 \\
P (Fosfor) (\%) & 0,77 & 0,72 & 0,66 & 0,60 \\
ME (Kkal) (\%) & 2986,64 & 2898,44 & 2810,24 & 2722,04 \\
\hline
\end{tabular}

Ket : Hasil Perhitungan berdasarkan komposisi zat-zat makanan dari Tabel 1.

Kandang yang digunakan adalah lain yang digunakan adalah timbangan kandang battery berukuran 40x30x30 cm, digital Ohaus (untuk menimbang ransum terdiri dari 20 unit yang dilengkapi dengan tempat makan dan minum. Perlengkapan dan telur), ember, kantong plastik, sapu, Koran dan lain sebagainya. 
Bahan pakan penyusun ransum terdiri dari jagung kuning, dedak halus, tepung kedele, tepung ikan, tepung keong sawah, bungkil kelapa dan $\mathrm{CaCO}_{3}$. Komposisi bahan pakan penyusun ransum dapat dilihat pada Tabel 1. Susunan komposisi ransum penelitian dan kandungan zat- zat makanan ransum percobaan dapat dilihat pada Tabel 2 dan Tabel 3.

Penelitian ini menggunakan Rancangan Acak Lengkap (RAL) menurut petunjuk Steel and Torrie (1995), yang terdiri dari 4 perlakuan dan 5 kali ulangan dengan menggunakan 3 ekor burung puyuh per unit.

Variabel yang diukur yaitu konsumsi ransum, produksi telur dan konversi ransum dengan menggunakan rumus :

1. Konsumsi ransum dapat dihitung berdasarkan rumus (Anggorodi, 1985) Ransum yang diberikan (g/ekor/hari) - ransum sisa (g/ekor/hari) dibagi dengan jumlah ternak

2. Produksi telur dihitung (\% Quail day production) berdasarkan rumus (Sudrajat et al., 2014) $\frac{\text { jumlah produksi telur (butir)x } 100 \%}{\text { jumlah puyuh pada saat penelitian }}$
3. Konversi ransum dihitung berdasarkan rumus (Handarini, 2008) $\frac{\text { total konsumsi pakan }(\mathrm{g})}{\text { berat telur }(\mathrm{g})}$

\section{HASIL DAN PEMBAHASAN}

Rataaan nilai konsumsi ransum, produksi telur dan konversi ransum dengan menggunakan tepung keong sawah sebagai pengganti tepung ikan pada burung puyuh dapat dilihat pada Tabel 4.

\section{Pengaruh Perlakuan Terhadap Konsumsi Ransum}

Rataan konsumsi ransum dapat dilihat pada Tabel 4. Rataan konsumsi ransum per ekor pada perlakuan berkisar antara 22,38 sampai 23,78 gram/ekor/hari. Dari rataan tersebut dapat dilihat bahwa konsumsi ransum relatif sama. Kisaran ini masih sesuai dengan standar kebutuhan yang direkomendasikan Sunarno (2004) menyatakan konsumsi ransum burung puyuh umur 21 sampai 55 hari sekitar 14 24 gram/ekor/hari. Selanjutnya Sany et al., (2015) menyatakan burung puyuh umur 70 hari mengkonsumsi ransum 20,92 sampai 23,32 gram/ekor/hari. 
Tabel 3. Rataan Nilai Konsumsi Ransum, Produksi Telur dan Konversi Ransum Selama Penelitian.

\begin{tabular}{lcccc}
\hline \multirow{1}{*}{ Variabel } & \multicolumn{3}{c}{ Perlakuan } \\
\cline { 2 - 5 } & $\mathrm{R} 0$ & $\mathrm{R} 1$ & $\mathrm{R} 2$ & $\mathrm{R} 3$ \\
\hline Rataan konsumsi ransum (gram/ekor /hari) & 23,78 & 23,41 & 23,71 & 22,38 \\
Rataan produksi telur (\%) & 61,07 & 60,35 & 60,47 & 60,71 \\
Rataan konversi ransum & 2,16 & 2,17 & 2,23 & 2,14 \\
\hline Keteran
\end{tabular}

Keterangan: Rataan konsumsi, produksi telur dan konversi ransum menujukkan pengaruh tidak berbeda nyata $(\mathrm{P}>0,05)$

Hasil analisis statistik menunjukkan bahwa penggunaan tepung keong sawah dalam ransum burung puyuh tidak menunjukan pengaruh yang nyata $(\mathrm{P}>0,05)$ terhadap konsumsi ransum. Tidak berbedanya konsumsi ransum disebabkan masing-masing ransum perlakuan mengandung energi yang sesuai kebutuhan burung puyuh. Kualitas dan kuantitas ransum yang diberikan dapat mempengaruhi tingkat konsumsi ransum burung puyuh. Hal ini menurut Ensminger (1992) konsumsi ransum merupakan kegiatan masuknya sejumlah nutrisi yang ada dalam ransum yang telah tersusun dari bahan ransum untuk memenuhi kebutuhan nutrisi ternak tersebut.

$$
\text { Menurut Scott et al }
$$
menyatakan bahwa pada hakekatnya unggas mengkonsumsi ransum untuk memenuhi kebutuhan energi . Selanjutnya menurut Anggorodi (1985) dan Nuraini et al. (2012) bahwa konsumsi pakan dipengaruhi oleh beberapa faktor antara lain: umur, palatabilitas ransum, kesehatan ternak, jenis ternak, aktivitas ternak, energi ransum, tingkat produksi, kuantitas dan kualitas ransum. Menurut Wahyu (2004) menyatakan bahwa konsumsi ransum dipengaruhi oleh zat zat makanan yang terkandung dalam ransum. Ransum yang diberikan pada ternak harus disesuaikan dengan umur dan kebutuhan ternak sebab pakan memiliki peranan penting untuk menjamin kelangsungan hidup puyuh dan produksi telurnya. Sebab burung puyuh cenderung memilih bahan pakan sumber energi kemudian dilanjutkan bahan pakan sumber protein (Irawan et al., 2012 ).

\section{Pengaruh Perlakuan Terhadap Produksi Telur (Quail day production \% )}

Rataan produksi telur burung puyuh berkisar antara $60,35 \%$ sampai $61,07 \%$ dapat dilihat pada Tabel 4. Dari rataan tersebut dapat dilihat bahwa produksi telur relatif sama. Hasil penelitian ini tidak jauh berbeda dengan hasil penelitian yang dilakukan oleh Tiwari dan Panda (1978) dimana produksi telur burung puyuh umur 5 sampai 6 minggu berkisar antara 54,75 sampai $67 \%$ Selanjutnya Choeronisa et al., (2016) menyatakan quail day production (\% ) pada burung puyuh fase layer (umur 
10 minggu) berkisar antara 48,41\% sampai $64,44 \%$.

Hasil analisis statistik menunjukkan bahwa penggunaan tepung keong sawah dalam ransum burung puyuh tidak menunjukkan pengaruh yang nyata $(\mathrm{P}>0,05)$ terhadap produksi telur. Walaupun produksi telur tidak berbeda nyata secara statistik namun pada Tabel 4 terlihat bahwa burung puyuh yang mendapatkan ransum dengan tingkat protein $20,78 \% \quad$ (R0) menghasilkan produksi telur yang tidak berbeda dibandingkan dengan ransum yang mengandung protein lainnya. $(\mathrm{R} 0=61,07$; $\mathrm{R} 1=60,35 ; \mathrm{R} 2=60,47 ;$ dan $\mathrm{R} 3=60,71)$.

Hasil penelitian ini menunjukkan bahwa produksi burung puyuh yang memperoleh ransum yang mengandung protein $20,78 \%$ lebih baik dibandingkan dengan burung puyuh yang memperoleh ransum protein rendah. Burung puyuh yang memperoleh ransum 20,78\% menunjukkan presentasi produksi telur yang lebih tinggi namun secara statistik produksi telur berbeda tidak nyata. Menurut Scott et al. (1982) menyatakan bahwa konsumsi protein yang rendah mengakibatkan laju produksi yang rendah.

Menurut Wahyu

menunjukkan bahwa penggunaan energi yang maksimal untuk tujuan produksi dapat dicapai apabila ransum mengandung asam amino dan zat lainnya yang seimbang. Yasin (1988) menyatakan bahwa secara garis besar produksi burung puyuh dipengaruhi oleh beberapa faktor antara lain, genetik, ransum, kandang, temperatur, lingkungan, penyakit dan stress. Diwayani et al. (2012); Hasan et al. (2003) menyatakan bahwa burung puyuh dengan berat badan 90 sampai 100 gram akan mulai bertelur umur 35 sampai 42 hari produksi telur dipengaruhi oleh strain, umur pertama bertelur, konsumsi pakan.

\section{Pengaruh Perlakuan Terhadap Konversi Ransum}

Rataan konversi ransum dapat dilihat pada Tabel 4. Rataan konversi ransum berkisar antara 2,14 sampai 2,23. Dari rataan tersebut dapat dilihat bahwa konversi ransum relatif sama. Menurut Kaselung et al. (2014) konversi ransum burung puyuh berkisar antara 2,32 sampai 2,48 .

Hasil analisis statistik menunjukkan bahwa penggunaan tepung keong sawah dalam ransum burung puyuh tidak menunjukkan pengaruh yang nyata $(\mathrm{P}>0,05)$ terhadap konversi ransum, hal ini disebabkan karena masing-masing perlakuan mengandung kandungan nutrisi yang sesuai dengan kebutuhan burung puyuh.

Angka konversi ransum rendah menandakan efisiensi ransum tinggi, 
sebaliknya angka konversi ransum yang tinggi menunjukkan nilai manfaat biologisnya yang rendah. Menurut Rasyaf (1991) bahwa konversi dapat digunakan sebagai gambaran koefisien produksi, semakin kecil nilai konversi semakin efisien penggunaan ransum dan demikian sebaliknya. Menurut Wahyu (2004) baik buruknya nilai konversi ransum ditentukan oleh berbagai faktor seperti pengolahan yang mencakup peralatan makanan yang dipakai, bentuk dan kwalitas dari ransum, umur ternak, bangsa, kandungan gizi ransum, keadaan temperatur, dan kesehatan ternak.

\section{KESIMPULAN}

Berdasarkan hasil penelitian menunjukkan tepung keong sawah sampai level $15 \%$ dapat digunakan sebagai pengganti tepung ikan dalam ransum burung puyuh.

\section{DAFTAR PUSTAKA}

Amo, M., J. L. P. Saerang, M. Najoan, dan J. Keintjem. 2013. Pengaruh penambahan tepung kunyit (Curcuma domestica val) dalam ransum terhadap kualitas telur puyuh (Coturnix-coturnix japonica). Jurnal Zootek Vol. 33(1): 48-57.

Anggorodi, H. R, 1985. Kemajuan Mutakhir Dalam Ilmu Makanan Ternak Unggas. Penerbit Universitas Indonesia. Jakarta.
Choeronisa S., Endang Sujana, dan Tuti Widjastuti. 2016. Performa Produksi Telur Puyuh (Coturnixcoturnix japonica) Yang Di Pelihara Pada Flock Size Yang Berbeda. Fakultas Peternakan Universitas Padjadjaran.

Dengah, S. P., J. F. Umboh, C. A. Rahasia dan Y. H. S. Kowel. 2016. Pengaruh penggantian tepung ikan dengan tepung maggot (hermetia illucens) dalam ransum terhadap performans broiler. Jurnal Zootek Vol. 36(1): 51-60.

Diwayani, R. M, D. Sunarti, dan W. Sarengat. 2012. Pengaruh pemberian pakan bebas pilih (Free choice feeding) terhadap performans awal peneluran burung puyuh

(Coturnix-coturnix japonica). Anima Agricultural Journal, Vol. 1(1): 23-32.

Ensminger. 1992. Poultry Science. Interstate Publishers. Inc. Illinois.

Handarini, R., E. Saleh dan B. Togatorop. 2008. Produksi burung puyuh yang diberi ransum dengan penambahan tepung umbut sawit fermentasi. Agribisnis Peternakan, Vol. 4(3): 107

Hasan, S. M., M. E. Mady, A. L. Cartwright, H. M. Sabri dan M. S. Mobarak. 2003. Effect of early feed restriction on reproductive performance in Japanese Quail (Coturnix-coturnix japonica). J. Poultry Sci, 82 : 1163-1169.

Irawan. I., D. Sunarti, dan L. D. Mahfudz. 2012. Pengaruh pemberian pakan bebas pilih terhadap kecernaan protein burung puyuh (coturnixcoturnix japonica). Animal Agriculture Journal, Vol. 1(2) 
Kaselung. P. S., M. E. K. Montong, C. L. K. Sarayar, dan J. L. P. Saerang. 2014. Penambahan rimpang kunyit (curcuma domestica val), rimpang temulawak (curcuma xanthorriza roxb) dan rimpang temu putih (curcuma zedoaria rosc) dalam ransum komersial terhadap performans burung puyuh (coturnixcoturnix japonica). Jurnal Zootek Vol. 34(1): 114-123.

NRC [National Research Council]. 1994. Nutrient Requirements of Poultry. Ed Rev ke-9. Washington DC. Academy Pr.

Nuraini, Sabrina dan S. A. Latif . 2012. Fermented product by Monacus purpureus in poultry diet effects on laying performance and egg quality. Pakistan Journal of Nutrition 11: 507- 510.

Paputungan, U. 1984. Performans Ayam Pedaging Yang Diberi Moluska Giling. Skripsi. Fakultas Peternakan Universitas Sam Ratulangi Manado.

Rasyaf, M. 1991. Memelihara Burung Puyuh. Cetakan Kesembilan. Yayasan Kanisius. Yogyakarta.

Sany. S. W., Setiana Rohmi Heswantari, Sudibya, Sutrisno Hadi Punormo dan Aqni Hanifa. 2015. Pengaruh suplementasi minyak ikan dan $l$ karnitin dalam pakan jagung kuning terfermentasi terhadap kecernaan pakan dan performa puyuh (Coturnix-coturnix japonica). Buletin Peternakan Vol. 39 (1): 3141.

Scott, M. L., M. C. Nesheim and R. J. Young. 1982. Nutrition of The Chicken. $\quad 3^{\text {nd }} \quad$.Ed. Cornell University. Ithaca, New York.
Steel, R.G.D. dan J.H Torrie, 1994. Prinsip dan Prosedur Statistika Suatu Pendidikan Giometrik, PT. Gramedia Pustaka Utama. Jakarta.

Sudrajat, D., D. Kardaya, E. Dihansih, S.F.S. Puteri. 2014. Performa produksi telur burung puyuh yang diberikan ransum mengandung kromium organik. JITV 19(4) : 257262.

Sugiantoro dan Nurul Hidajati. 2013. Karakterisasi protein kasar dan lemak kasar untuk menentukan kualitas tepung cacing sutra (tubifex $s p$ ) dibandingkan tepung ikan berdasarkan lama penyimpanan. UUNESA Journal of Chemistry Vol. 2(3):

Sunarno. 2004. Potensi Burung Puyuh Majalah Poultry Indonesia Edisi Februari. Hal: 61.

Tiwari, K. S., B. Panda. 1978. Production and quality characteristics of quail eggs. Indian Journal of Poultry Sci 13(1): 27-32

Wahyu, J. 2004. Cetakan ke-5. Ilmu Nutrisi Unggas. Gadjah Mada University Press, Yogyakarta

Widyatmoko. H., Zuprizal, dan Wihandoyo, 2013. Pengaruh penggunaan corn dried distillers grains with solubles dalam ransum terhadap performan puyuh jantan. Buletin Peternakan. Vol. 37(2): 120124.

Yasin, S. 1988. Fungsi dan Peranan Zat- zat Gizi dalam Ransum Ayam Petelur. Mediatama Sarana Perkasa. Mataram. Page 41-43. 